\title{
TRIBAL PROPERTY INTERESTS IN EXECUTIVE-ORDER RESERVATIONS: A COMPENSABLE INDIAN RIGHT
}

WHETHER the United States must compensate Indian tribes for the taking of land in reservations created by and held under Executive order principally depends on whether Congress has "recognized" tribal property interests in such land. After a century and a half of sovereign non-consent to suit, ${ }^{1}$ the Indian Claims Commission Act of 1916 extended jurisdiction of the Court of Claims to Indian claims against the Government accruing after 1946 and arising under the "Constitution, laws or treaties of the United States, or Erectrtive Orders of the President ...." This general grant of jurisdiction, however, incorporates a requirement that a claim be based on legal or equitable rights. ${ }^{3}$ And the Supreme 'Court has held, in cases involving land taken dur-

1. Prior to 1946, Indian tribes could sue the United States, which may not be sued without its consent, see United States v. Clarke, 33 U.S. (8 Pet.) 436 (1834) (dictum), only if the federal government consented to suit in a special jurisdictional statute, sec, e.g., Act of Aug. 26, 1935, ch. 686, 49 Stat. 801.

2. Indian Claims Commission Act, ch. 959, § 24, 60 Stat. 1055 (1946) (now 28 U.S.C. $\S 1505$ (1958)). (Emphasis added.) The act created a Claims Commission to hear among other Indian claims, those accruing prior to August 14, 1946, and "arising from the tal:ing by the United States . . . of lands owned or occupied by the claimant without the payment of ... compensation," and those "based upon fair and honorable dealings that are not recognized by any existing rule of law and equity." Indian Claims Commission Act $\S \S 2(4)-(5), 60$ Stat. 1050 (1946), 25 U.S.C. $\S \S 703(4)-(5)$ (1958). All Indian claims accruing prior to 1946 and not filed with the Commission within five years after passage of the act were barred. Section 12, 60 Stat. 1052 (1946), 25 U.S.C. $\$ 70$ : (1958); see Note, 15 Geo. Wash. L. Rev. 388 (1947); Note, 69 Harv. L. REv. 119, 147-51 (1955). The Commission was created (1) to eliminate the large backlog of pre-1946 claims unheard as a result of sovereign nonconsent to suit, (2) to do away with the prolonged, expensive, and inequitable process of obtaining special jurisdictional statutes, (3) to relieve Congress of a burden to which it was illsuited, and (4) to obtain a uniform interpretation of Indian land interests. H.R. REP. No. 1466, 79th Cong., 1st Sess. (1945); Hearings on H.R. 1198 and H.R. 1341 Before the Honse Commillee on Indian Afjoirs, 79th Cong., 1st Sess. 68 (1945) (to end harassment of Congress); id. at 88 (took over 90 years to get special jurisdictional statute and recovery); U.S. DEP'T of IHE INTERIOR, FEDERAL INDIAN LAW 347-48 (1958) [hereinafter cited as Federal IxDLAx LAw] (varicty of standards in pre-1946 special jurisdictional statutes).

3. Indian Claims Commission Act, ch. 959, § 24, 60 Stat. 1055 (1946), incorporates by reference the jurisdictional requisites of Act of March 3, 1911, ch. 231, $\$ 145,36$ Stat. 1136. The incorporating language is omitted from the Judiciary Act codification in the United States Code "as unnecessary since the Court of Claims manifestly . . . will determine whether a petition ... states a cause of action." Reviser's sNote following 23 U.S.C. $\S 1505$ (1952) (now following 28 U.S.C. \& 1491 (1958)).

The jurisdiction of the Court of Claims, unlike that of the Indian Claims Commission, does not extend to claims "not recognized by any existing rule of law and equity:" See note 2 supra. Compare Otoe \& Missouria Tribe of Indians v. United States, $131 \mathrm{Ct} . \mathrm{Cl}$. 593, 131 F. Supp. 265, cert. denied, 350 U.S. 848 (1955), with Tee-Hit-Ton Indians v. United States, 348 U.S. 272 (1955). 
ing the nineteenth century, that Indian tribes have neither legal nor equitable rights to Executive-order lands. ${ }^{4}$ Moreover, both the Supreme Count and a federal district court have noted obiter, without qualification as to the date a claim accrued, that an Executive order creating an Indian reservation confers only a right of use or occupancy subject to the pleasure of Congress, which may terminate such rights without legal liability for compensation." If these decisions control property claims accruing after 1946 and arising under Executive order, the apparent protection afforded an historic and important source of Indian property interests by extension of court jurisdiction to claims arising under "Executive Orders of the President" is rendered illusory."

Indian tribes ${ }^{7}$ in the United States, except in Alaska, reside on reservations created by treaty, statute, or Executive order. Originally, reservations were, for the most part, established by treaty. ${ }^{8}$ In 1871 , however, Congress prohibited further use of the treaty power in Indian affairs, ${ }^{0}$ and the President, assuming the function formerly exercised by Congress, thereafter set aside twenty-three million acres of the public domain by Executive order for the use and occupancy of Indian tribes.10 In 1919, when most tribal Indians were settled on reservations, Congress forbade further use of the Executive order

4. Sioux Tribe of Indians v. United States, 316 U.S. 317 (1942) ; Confederated Bands of Ute Indians v. United States, 330 U.S. 169 (1947).

5. Hynes v. Grimes Packing Co., 337 U.S. 86, 103 (1949) (dictum) ; Healing v. Jones, 174 F. Supp. 211, 216 (D. Ariz. 1959) (dictum).

6. Executive orders have been used in Indian affairs almost exclusively for the creation or modification of reservations and Indian property interests therein. See 1 KAIPLER, Indian AfFaIRS: LAwS AND Treaties 801-936 (1904) [hereinafter cited as Kappler]. The five volumes of Kappler collect all executive orders relating to Indian affairs up to 1939. Executive orders issued pursuant to 24 Stat. 388 (1887), 25 U.S.C. $\S 331$ (1958), and 34 Stat. 325-26 (1906), 25 U.S.C. $\$ 391$ (1958), however, extended the trust period of restricted alienation for land allotted to individual Indians under the Indian General Allotment Act, 24 Stat. 388 (1887), as amended, 25 U.S.C. $\$ \S 331-34,336,339,341-42$, 348-49, 381 (1958). See, e.g., orders collected in 4 KAPPLER 1001-56.

7. In Cherokee Nation v. Georgia, 30 U.S. (5 Pet.) 1 (1831), Indinn tribes were determined to be "domestic dependent nations" under exclusive federal jurisdiction, yet retaining rights of sovereignty not expressly altered by Congress. The members of these tribes as determined by regulation of the tribe and the Secretary of Interior, sce FEDERaL INDIAN LAw 413-23, are tribal Indians subject to the privileges and restrictions of tribal law and federal Indian legislation. Any tribal Indian may renounce his tribal ties, id. at 419 , and leave the tribal reservation to become a citizen with rights and duties identical to non-Indian citizens. This Note is concerned only with Indian tribes and their members.

8. Federal Indian Law 138-39; 67 Cong. Rec. 10913 (1926).

9. 16 Stat. 566 (1871), 25 U.S.C. \& 71 (1958). This statute was passed, at House insistence, to end Senate control over Indian affairs. WALKER, THE INDIAN QUESTION 1112 (1874); SCHMECKEBIER, OFFICE of INDIAN AFFaIRS 56-58 (1927) (both reprinted in Federal Indan Law 211-12).

10. H.R. Rep. No. 2503, 82d Cong., 2d Sess. 60 (1953) ; 67 CoNG. ReC. 10913 (1926); Hearings on H.R. 9133 Before a Subcommittee of the House Committee on Indian Affairs, 69th Cong., 1st Sess. 41 (1926); Hearings on S. 1722 and S. 3159 Before a Subcommittee of the Senate Committee on Indian Affairs, 69th Cong., 1st Sess. 73, 75-76 (1926) [hereinafter cited as 1926 Senate Hearings I]. 
to create reservations, ${ }^{11}$ and subsequent minor withdrawals from the public domain were made by statute. ${ }^{12}$ To settle Indian property rights in Alaska, Congress, in 1936, delegated authority to the Secretary of Interior to designate reservations without additional statutory ratification. ${ }^{13}$ Since 1871 , therefore, the principal source of tribal property interests has been the Executive order. ${ }^{14}$

The legal nature of Indian property interests in Executive-order reservations ultimately derives from the "right of conquest or discovery."1s Under

11. 41 Stat. 34 (1919), 43 U.S.C. \$ 150 (1958). This statute extended a prior prohibition applicable only to lands in Arizona and New Mfexico. 40 Stat. 570 (1918), 25 U.S.C. § 211 (1958). Senators from these states feared the continued expansion of federal park, forest, and Indian reservations. 1926 Senate Hearings I, at 52. Since the 1919 prohibition was a part of legislation granting tribal Indians valuable mineral rights, the prohibition was probably enacted to prevent further extension of these rights without congressional approval. Compare 44 Stat. 1347 (1927), 25 U.S.C. $\$ 398 d$ (1958), enacted to prevent revocation of existing Executive-order reservations except by statute in order to protect Indian property interests. Hearings on H.R. 15021 Before the House Conmaitlee on Indian Affairs, 69th Cong., 2d Sess. 43 (1927) [hereinafter cited as 1927 House Hearings]. No revocation of an Executive-order Indian reservation in existence in 1927 has been made.

12. After 1919, additions to existing reservations were made through temporary withdrawal by the Secretary of the Interior followed by statutory ratification. See, e.g., Act of May 21, 1926, ch. 357, 44 Stat. 614; S. Rep. No. 725, 69th Cong., Ist Sess. (1926); Act of June 2, 1926, ch. 434, 44 Stat. 679; S. REp. No. 361, 69th Cong., 1st Sess. (1926). Statutes constitute a minor source of Indian property interests, H.R. REp. No. 2503, 82d Cong., 2d Sess. 60 (1953).

13. 49 Stat. 1250 (1936), 48 U.S.C. $\$ 358 a$ (1958); see note 70 infro and accompanying text.

14. Of the 23 million acres set aside by Executive order, see note 10 supra and accompanying text, approximately 12 million have been allotted as restricted fees to individual Indians under the authority of the Indian General Allotment Act, 24 Stat. 388 (1887), as amended, 25 U.S.C. \& 331 (1958). Nine million acres were consolidated by statute into the Navaho reservation. Act of June 14, 1934, ch. 521, 48 Stat. 960. Over two million acres of tribal land are presently held under Executive order only. See H.R. REP. No. 2503, 82d Cong., 2d Sess. 60-74 (1953).

15. The "right of conquest or discovery" was first stated in dictum by Chief Justice Marshall in Johnson v. MÍcIntosh, 21 U.S. (8 Wheat.) 543 (1823), and reiterated in Worcester v. Georgia, 31 U.S. (6 Pet.) 515 (1832); Mitchel v. United States, 34 U.S. (9 Pet) 711, 734-35 (1835) ; Northwestern Bands of Shoshone Indians v. United States, 324 U.S. 335 (1945). The language of the early cases was ambiguous, however, and it was not clear whether conquest gave the United States the right to take land claimed by aboriginal title without compensation or the exclusive right to purchase. See Worcester v. Georgia, 31 U.S. (6 Pet.) 515, 545 (1932) ("discovery . . gave the exclusive right to purchase, but did not found that right on a denial of the possessor to sell"); Mitchel v. United States, 34 U.S. (9 Pet) 711, 745 (1835) ("their [the Indians] right of oecupancy is considered as sacred as the fee-simple of the whites"). In 1946, the Supreme Court held, in a case arising under a special jurisdictional statute, that the United States is constitutionally required to compensate Indians for the taking of land claimed by aboriginal title. United States v. Alcea Band of Tillamooks, 329 U.S. 40 (1946). The Court's statement, "By this Act Congress neither admitted nor denied liability . . . . No 
this doctrine, absolute title to all land occupied by Indian tribes vested in the United States as a conquering nation. The tribes retain, however, a right of use and occupancy legally valid against all but the Government, which, by an act of extinguishment, may take the land without compensation. But congressional "recognition" of the right of use and occupancy converts it into a compensable interest-equitable title. ${ }^{16}$ Treaties establishing reservations constitute such acts of "recognition," and vest permanent equitable title to the land in the tribe, with legal title held in trust by the United States. ${ }^{17}$

But treaty ratification is not the only manner in which Congress can convert a tribe's right of use and occupancy into equitable title. Thus, Sioux Tribe of Indians $v$. United States, ${ }^{18}$ while holding that the Executive has no inherent power to give Indian tribes compensable property interests, ${ }^{10}$ apparently accepted two theories whereby tribes may obtain vested rights in Executive-order reservations. First, the Executive may acquire power to vest Indian property interests from indirect congressional delegation: congressional acquiescence in the Executive practice of establishing reservations coupled with congressional understanding that such establishment vested rights in the

new right or cause of action is created. A merely moral claim is not made a legal one," $i d$. at 45 , indicates that allowance of the claim was based not on a statutory direction to pay, but a constitutionally compensable interest; see Note, 60 HARv. L. Rev. 465 (1947). A lower federal court so interpreted the decision. Miller v. United States, 159 F.2d 997 (9th Cir. 1947). But in a subsequent decision concerning the interest dite on the claim allowed in Alcea I, the Supreme Court, disallowing interest, implied that its prior decision was based only on a legislative direction to pay. See United States v. Alcea Band of Tillamooks, 341 U.S. 48 (1951). If Alcea $I$ had been based on any interest compensable under the fifth amendment, the 'Court would have had to allow interest on the claimsome $\$ 14$ million, id. at 49 . In 1954 , the Supreme Court held that Congress could take land claimed by aboriginal title without compensation. Tee-Hit-Ton Indians v. United States, 348 U.S. 272 (1955). The Indian Claims Commission has granted recovery to Indian tribes for takings of land held under aboriginal Indian title. Otoe \& Missouria Tribe of Indians v. United States, $131 \mathrm{Ct}$. Cl. 593, $131 \mathrm{~F}$. Supp. 265, cert. denticd, 350 U.S. 848 (1955).

For general discussions of Indian title, see F. S. Cohen, Original Indian Tille, 32 Minn. L. Rev. 28 (1947); Federal Indian LAw 593-601.

16. "There is no particular form for congressional recognition of Indian right of permanent occupancy. It may be established in a variety of ways but there must be the definite intention by congressional action or authority to accord legal rights, not merely permissive occupation." Tee-Hit-Ton Indians v. United States, 348 U.S. 272, 278-79 (1955).

17. Compensation for the taking of "recognized" tribal land was granted in United States v. Klamath \& Mloadoc Tribes of Indians, 304 U.S. 119 (1938); United States v. Shoshone Tribe of Indians, 304 U.S. 111 (1938); Shoshone Tribe of Indians v. United States, 299 U.S. 476 (1937) ; United States v. Creek Nation, 295 U.S. 103 (1934); Yankton Sioux Tribe v. United States, 272 U.S. 351 (1926); United States v. Mille Lac Band of 'Chippawa Indians, 229 U.S. 498 (1913). See also Coos Bay Indian Tribe v. United States, $87 \mathrm{Ct}$. Cl. 143, 153 (1938) (an unratified treaty not "recognition").

18. 316 U.S. 317 (1942).

19. Id. at 326: accord, Confederated Bands of Ute Indians v. United States, 329 U.S. 169 (1947). 
Indians. ${ }^{20}$ Under this theory, the Indians would acquire compensable property interests when the Executive order creating the reservation is issued. Second, a statute may constitute recognition of tribal property interests in a reservation defined by Executive order and in existence at the passage of the statute. ${ }^{21}$ Under this theory, tribal property interests would become compensable with passage of the statute constituting recognition. Applying these theories to the facts of Sioux-an 1884 taking of land added to a reservation by Executive order in 1875-the Court considered the effect of the Indian General Allotment Act, ${ }^{22}$ which had authorized the President to allot a restricted fee simple to any individual Indian residing on a treaty, statutory, or Executiveorder reservation, and held that neither indirect delegation nor recognition had occurred, 23

Although between 1887 and 1919, when the Executive order in Indian affairs was abolished, Congress did not directly or indirectly delegate authority to the Executive to create vested Indian interests in Executive-order reservations, the content and legislative history of a 1927 statute providing for the lease of oil and gas rights in such reservations indicate that Congress intended that statute to be an act of recognition. The statute provides:

Unalloted lands within the limits of any reservation or withdrawal created by Executive order for Indian purposes or for the use or occupancy of any Indians or tribe may be leased for oil and gas mining purposes in accordance with the provisions contained in the Act of Mlay 29, 1924 (Forty-third Statutes, page 244) [leasing act for treaty reservations].

20. 316 U.S. at 326 . The origin of this doctrine was United States v. Midwest Oil Co., 236 U.S. 459 (1915), which held that by virtue of a long-established practice of creating Indian and military reservations by Executive order the President had power to withdraw lands from the public domain in order to immunize them from a leasing statute. See Mason v. United States, 260 U.S. 545 (1923). Previous lower court decisions had held that reservations created by the Executive were not subject to gencral leasing statutes, McFadden v. Mountain View Min. \& Miill. Co., 97 Fed. 670 (9th Cir. 1599), rev'd on jurisdictional grounds, 180 U.S. 533 (1901); Gibson v. Anderson, 131 Fed. 39 (9th Cir. 1904).

21. The court did not discuss this theory of congressional "recognition" in detail since the statute upon which the plaintiff relied, the Indian General Allotment Act, 24 Stat. 388 (1887), as amended, 25 U.S.C. $\$ 331$ (1958), was not passed until three years after the land in question was returned to the public domain. 316 U.S. at 330. As argued by the appellee: "The general allotment act ratified and confirmed Exceutive Orders creating Indian reservations which were in effect on the date of the act, February 8, 1857." Brief for the Appellee, p. 17, Sioux Tribe of Indians v. United States, 316 U.S. 317 (1942). The court replied in dictum that the statute "did not amount to a recognition of tribal ownership of the [Executive order] lands [referred to in the Act] . . ." 316 U.S. at 330 .

22. 24 Stat. 388 (1887), as amended, 25 U.S.C. $\S \S 331-34,336,339,341-42,348-49$, 381 (1958).

23. Prior to Sioux Tribe, it had been believed that the doctrine of Mfidwest Oil, in addition to confirming Executive power to set aside land for the use of the Indians, see note 20 supra, also confirmed Executive power to vest a compensable property interest in the tribe, see 34 OpS. ATT'Y GEN. 171 (1924). 
... [T] $]$ he proceeds ... shall be deposited in the Treasury of the United States to the credit of the tribe of Indians for whose benefit the reservation or withdrawal was created or who are using and occupying the land ....24

Passage of this statute was occasioned by conflicting interpretations of a 1920 act which provided for the lease of oil and gas rights in "land . . . owned by the United States."25 Applications for leases of Executive-order lands were granted by the Secretary of the Interior on the ground that equitable as well as legal title was in the Government. ${ }^{20}$ But Attorney General Harlan Fiske Stone ruled that Executive-order reservations were not subject to lease under the statute because (1) the act clearly did not apply to treaty or statutory reservations and neither the courts nor Congress had ever made a distinction as to the character and extent of Indian rights in treaty, statutory, or Executive-order reservations; and (2) Executive orders probably vested an equitable fee in the Indians. ${ }^{27}$ The Attorney General's opinion was overruled by a district court, which held that legal and equitable title was in the United States $;^{28}$ and the Court of A.ppeals, without opinion, certified questions to the Supreme Court. ${ }^{29}$ The suit was mooted by passage of the 1927 statute.

The legislative history of the 1927 statute spanned three annual sessions of Congress-from 1925 to 1927 . In 1925, a bill providing that royalties from gas and oil leases in Executive-order reservations be split among the Indian tribes, states, and federal government was passed by the Senate but tabled in the House on a procedural point of order. ${ }^{30}$ In 1926 , a bill, substantially the

24. 44 Stat. 1347 (1927), 25 U.S.C. $\$ \S 398 a-e$ (1958).

25. Mineral Lands 'Leasing Act, 41. Stat. 437 (1920), as amended, 30 U.S.C. $\$ \S 181$ 229 (1958).

26. E. M. Harrison, 49 Interior Land Dec. 139 (1922).

27. 34 Ops. ATT'Y GEN. 171 (1924). A third ground for Stone's opinion was that general legislation does not apply to Indian territory in the absence of an express stipulation or clear intention in the legislative history. Id. at 172-75, citing Ex partc Crow Dog, 109 U.S. 556 (1883).

28. United States v. Harrison, Equity No. 8288, D. Utah, March 3, 1925, reprinted in Hearitgs on H.R. 9133 Before a Subcommittee of the House Commiltec an Indian Affairs, 69th Cong., 1st Sess. 82-83 (1926). Defendant had received a permit to search for oil on an Executive-order reservation and in reliance on the opinion of the Secretary of the Interior, note 26 supra, incurred substantial expenditures. The Attorney General's office brought suit in the district court subsequent to the Attorney Gencral's opinion, note 27 supra, to cancel the exploration permits. The exact rationale of the court's holding for defendant-permittee is unclear; for in addition to stating that legal and equitable title was in the Government, the court emphasized that (1) the land in question had never been occupied by Indians, and: (2) the hardship to the defendant who had in good faith incurred expenditures out-weighed the "highly technical" argument of the United States.

29. United States v. Harrison, No. 872, U.S., Oct. Term 1925, reprinted in 1927 House Hearings 10-11.

30. S. 876, 68th Cong., 1st \& $2 \mathrm{~d}$ Sess. (1924-1925). The history of this bill is complex. As first reported from the Senate Committee on Indian Affairs, S. REP. No. 669, 68th Cong., 1st Sess. (1924), and passed by the Senate, 66 CoNG. Rec. 999 (1924), all 
same as the legislation eventually enacted, giving all royalties to the tribes was passed by both House and Senate, ${ }^{31}$ but vetoed by the President. ${ }^{32}$ The statute, in its present form, was introduced, passed by House and Senate, and signed by the President in 1927.33 The royalty provision vitally affects the question of whether Indian tribes have title to Executive-order reservations. Congressional allocation of royalties to the state and federal governments as provided in the 1925 bill implied that complete ownership of Executive-order land was in the United States. ${ }^{34}$ Retention of the entire proceeds in trust for the Indians, as provided in the final statute, implied congressional recognition of equitable title in the tribe. ${ }^{35}$

royalties from gas and oil leases on Executive-order reservations were to go to the Indian tribe. The bill was amended and passed in the House to allow the states to tax the proceeds. H.R. REP. No. 1254, 68th Cong., 2d Sess. (1925); 66 CoNG. Rec. 2234 (1925). The House amendment was amended by the Senate to provide that 37:8\% of the lease royalties go to the $S$ tate, $52 \mathrm{x} / 2 \%$ to the federal government, and $10 \%$ to the tribes. $I d$. at 2799. The purpose of the Senate amendment was to prevent the states from overtaxing the tribes. Id. at 5433 (remarks of Mr. Hayden) ; Hearings on H.R. 9133 Before a Subcommittee of the House Conmittee on Indian Affairs, 69th Cong., 1st Sess. 26-27 (1926) (amended to protect Indians). The House objected to the amended bill, which then went to joint conference for study not of the original text but of the amendment. When the bill was reported from conference to the House, H.R. REP. No. 1637, 68th Cong., 2d Sess. (1925), a point of order was raised on the ground that the joint conference cxceeded the scope of its authority by altering text upon which both Houses had previously agreed. The point of order was sustained and the bill tabled. 66 CoxG. REC 5433-34 (1925). The point of order was raised by pro-Indian legislators. 1926 Sencle Hearings I, at 55. This opposition is at first glance surprising since the royalty splitting provision was added to protect the Indians. That the title implications of this provision was the ground of opposition emerges from hearings held the following year. See notes 34-35 infra.

31. 67 CoNG. Rec. 10912 (S. 4152 read into the Recurd) (1926); id. at 10925 (passed by Senate) ; $i d$. at 11397 (passed by House, with minor amendment); id. at 11530 (House amendment accepted by Senate).

32. S. Doc No. 156, 69th Cong., 1st Sess. (1926) (President's veto message). Under the Mineral Lands Leasing Act, 41 Stat. 437 (1920), as amended, 30 U.S.C. $\$ \$ 181-229$ (1958), and prior to the Attorney General's opinion holding that the act did not apply to Executive-order reservations, see note 27 supra, there were approximately 400 applications filed for exploration permits on Executive order land, 20 of which were granted. The President believed that $\$ 3$ of S. 4152, supra note 31, designed to treat equitably permittees who had incurred exploration expenses, discriminated between applicants and permittees. He therefore vetoed the bill, but expressed his willingness to sign another bill eliminating this discrimination. S. Doc. No. 156, supra. See also 1927 House Hearings 14-15 (remarks of Commissioner Burke).

33. 67 Cons. Rec 2793 (passed by Senate) (1927); id. at 4581 (passed by House); id. at 5529 (signed by President); 44 Stat. 1347 (1927), 25 U.S.C. $\$ \$ 3982-c$ (1958).

34. See 1926 Senate Hearings $I$, at 71; Hearirgs on $S .3159$ and $S .4152$ Before the Sentate Committee on Indian Affairs, 69th 'Cong., 1st Sess. 17 (1926) (remarks of Senator La Follette: "If the Government can divide these royalties it settles the question that the rights of the Indians are invalid.") [hereinafter cited as 1926 Senate Hearings II].

35. 1926 Senate Hearings II, at 21 (remarks of Senator Bratton, "If ve give the Indians all of it [the royalties], we are unqualifiedly recognizing their title to all Exeeutive order lands and can never recede from that position."). 
This relationship between title to Executive-order reservations and allocation of lease royalties was carefully considered by the Senate in 1926 and the House in 1927. At Senate hearings resulting in recommendation of the 1926 bill, ${ }^{30}$ the chairman of the Committee on Indian Affairs stated:

This is a very important bill, because for the first time we are really recognizing that the Indians have a title to Executive-order land . . . . It is a matter of doubt at the present time as to what their rights are in Executive-order lands, but there will be no doubts after the passage of this bill, because I think the passage ... will affirm title in the Indian tribes. ${ }^{37}$

Senator Bratton, representing the views of those opposed to recognizing Indian property interests, requested the committee to recommend an amendment that the act not be construed to vest title in the Indians. ${ }^{38}$ In response, the committee chairman stated: "[T] he time has come when the Government ought to confer title on the respective Indian tribes to these Executive-order lands, and I am willing for this bill to read in such a way as to do that."ao

36. Bills splitting the royalties were considered by a Subcommittee of the Senate Committee on Indian Affairs. 1926 Senate Hearings 1 . The full committee then considered one bill splitting the royalty and one bill giving all the proceeds to the tribes, 1926 Sctuatc Hearings $I I$, reporting the latter to the Senate floor, S. REp. No. 768, 69th Cong., 1st Sess. (1926) ; 67 CoNG. Rec. 8874 (1926).

37. 1926 Senate Hearings $I I$, at 48; see $i d$. at 14 (remarks of Senator Whecler: "Congress is not going to say we are giving them a gratuity. Congress is going to say: We recognize the equities there. We recognize that the Indians, as a matter of equity, arc entitled to that [royalties], and in good conscience we are going to try to give you something which in our judgment really belongs to you."); id. at 21-23 (remarks of Senator La Follette).

38. Id. at 76; see id. at 10-13, 29-34. Senator 'Bratton's proposed amendment was similar to provisions contained in two prior statutes, Act of July 1, 1892, ch. 140, 27 .Stat. 62, 63; Act of February 20,1893, ch. 147, 27 Stat. 469, 470. The Supreme Court cited such provisions to support the proposition that Congress did not intend to "recognize" tribal title to Executive-order lands. Sioux Tribe of Indians v. United States, 316 U.S. 317, 330-31 (1942).

39. 1926 Senate Hearings $I I$, at 78 . The chairman wished at this time to amend the bill expressly to confer title to Executive-order reservations on the Indian tribes. The committee believed, however, that such an amendment would precipitate a heated debate on the title issue in the Senate. Id. at 78-84. But, as Senator Bratton proplietically pointed out, "If . . . [the bill] goes to the floor in the present shape [without an amendment expressly directed to the title issue] it will necessarily provoke that controversy [debate on the title issue] there." Id. at 82 . It was argued at this.point in the hearings, id. at .81, and on several other occasions, 67 CoNG. REC. 10914 (1926) (remarks of Senator Jones), that $S .4152$ might be passed without touching the question of title, that is--could create in the Indians mineral rights in Executive-order land determinable at will by Congress without liability for compensation. Members of the committee believed, however, that the royalties could not be disposed of without settling the title issue. 1926 Senatc Hicarings II, at 16-17 (remarks of Senator Kendrick):

Suppose you have a withdrawal for Indian purposes, and you should procecd to develop it for oil . . . and then dispose of the royalty . . . to the Indians . . . . Then suppose that the withdrawal is again returned to the public domain, you 
Senator Bratton's proposed amendment was rejected by the committee. ${ }^{40}$ During the subsequent debate on the floor of the Senate, Senator Bratton, introducing another amendment designed to give protection to persons who applied for leases in Executive-order reservations under the MFineral Lands Leasing Act, said: "If the title was in the Indians, my amendment should not be adopted. If the title to the land was in the Government, the applicants had the right to file upon the land and should be protected . . . in the amendment, and the amendment should be adopted." $\$ 1$ Senator La Follette, in opposition to the proposed amendment, discussed in detail the judicial and legislative history of Executive-order reservations, concluding "that the right of occupancy is the right of ownership in so far as these Indians are concerned." The Senate overwhelmingly endorsed the position of Senator La Follette, rejected the amendment, and passed the bill giving all royalties from oil and gas leases in Executive-order reservations to the Indian tribes. ${ }^{43}$

In 1927, the House Committee on Indian Affairs recommended the bill which eventually passed. ${ }^{44}$ That the committee regarded the bill as congres-

would have a situation that is impossible, because the resources have been taken out of the land as the property of one owner, and the land returned to the public domain as the property of another owner. It seems to me, until that question of a definite title is ... definitely settled, there is no opportunity to proceed with the development.

Accord, id. at 82 (Senator Bratton: ". . . the effect of the bill without this amendment [see text at note 38 supra] would put Congress conclusively on the record as recognizing the title of the Indians"); ibid. (Senator La Follette: ". . . in so far as this act has to deal obliquely with the question of title, it seems to me that Congress should take a position which looks towards the confirmation of the title of the Indians to these Exeeutive order lands").

40. Id. at 84.

41. 67 Cong. REC 10918 (1926). Senator Bratton believed that if Executive-order lands were public domain, then the 400 lease applicants under the 1920 General Leasing Act had a legal right "to file upon the land as they did .... In that way the question of title becomes very material ...." Ibid. For Senator Bratton's position on Exceutiveorder lands, see id. at 10913-19 "If the Indians own the title to these lands so that they own the minerals under them, the President has vested that title in them by presidential proclamation in the face of a constitutional provision [art. IV, \& 3] vesting that authority in the Congress.").

42. Id. at 10922. For Senator La Follette's position, see id. at 10920:

... Congress did not intend when it ended the treaty-making power [see note 9 supra and accompanying text] to change the nature of the Indian ownership in reservations previously created or to be created in the future; and that the Indian ownership in the case of Executive-order reservations has been recognized by Congress as being identical with the ownership in the case of treaty rescrvations.

See generally id. at 10920-25.

43. Id. at 10925. See also 68 CoNG. Rec. 2793 (1927) (remarks of Senator Bratton with respect to the 1926 passage of S. 4125: "I found that the sentiment in the Senate was overwhelmingly in favor of giving the entire royalty to the Indians . . .").

44. H.R. REP. No. 1791, 69th Cong., 2d Sess. (1927).

During the 1926 congressional session, House hearings held on a bill splitting the lease royalties did not cover the title issue. See Hearings on H.R. 9133 Before a Subcons- 
sional recognition of Indian title is evidenced by the following remarks of the committee chairman:

I think it ought to be plain, and I think it is from the record of the debate and the original hearings, that the decision of the committee, the majority of the committee, has been that, regardless of what the Supreme Court might find the law to have been, there is a duty on the part of Congress to see that the law shall be such that the rights of the Indians as they ought to be are protected. If from failure of Congress to act in the past these rights have oozed out, it is our duty as legislative representatives and guardians of the Indians to act. ${ }^{45}$

Prior to House debate, Representative Sproul objected to consideration of the bill on the ground that under House rules a disposal of government property must first be considered by a Committee of the Whole. ${ }^{40}$ After calling the attention of the House to the importance of the dispute and hearing argument on both sides of the title issue, ${ }^{47}$ the Speaker of the House ruled that the bill disposed not of government property but "of lands held in trust for the Indians . . . "48 During subsequent debate, a member of the Committee on Indian Affairs, explaining the bill to the House, concluded that "it will validate Indian title to Executive order reservations and settle the question for all time."49 Representative Sproul, opposing passage of the bill, presented the legislative and judicial history of Executive-order reservations in an at-

mittee of the House Committee on Indian Affairs, 69th 1Cong., 1st Sess. (1926). The bill was reported to the floor but was returned to committee for amendment conforming it to the 1926 .Senate bill granting all royalties to the Indians. See 67 Cong. REc. 11379 (1926). It emerged from committee, however, with the following statement in the House Report: "Nothing in this bill is intended to in any manner change or alter the ownership or legal and equitable title to the lands described by its terms." H.R. REP. No. 763, 69th 'Cong., 1st Sess. 8 (1926). Compare this with the Act of July 1, 1892, ch. 140, $\$ 8,27$ Stat. 64 . (This disclaimer clause was omitted from the House Report on the leasing bill in 1927, H.R. REP. No. 1791, 69th Cong., 2d Sess. (1927)). Nonetheless, the bill was debated on the floor of the House. Both sides of the title issue were discussed, see 67 Cong. REc. 11379-97 (1926), and the chairman of the House Committee on Indian Affairs asserted that the bill would confer title to Executive-order reservations to the Indian tribes: "One of the principal purposes of this bill is to settle that [title] question in favor of the Indians and to decide by an act of Congress that they have the legal title to their lands and to the resources of their lands." Id. at 11381 .

45. 1927 House Hearings at 12-13; see id. at $88-89$ ("Tue Chairman. . . we will enact legislation that will determine that the Indians have a right in this mineral and this oil. MR. Brighans. You mean create a right now? Mr. Chimikman. Create it if it does not exist, regardless of what the Supreme Court might say as to what the law is now."); id. at 113 .

46. See 68 Cong. Rec. 4569 (1927).

47. Id. at $4569-72$.

48. Id. at 4572 .

49. Id. at 4575 (remarks of Mr. Frear); see id. at 4573-75, 4578-81. See also id. at 4578-79:

MR. GARTER. . . . So far as I know, the courts have never passed upon the difference between the rights of the Indians in a treaty and Executive order reser- 
tempt to prove that the affected land was public domain; ${ }^{50}$ and the House, with full awareness of the title implications, passed the bill as recommended by the committee. ${ }^{51}$ The Senate reaffirmed its 1926 position that the tribes had equitable title to Executive-order reservations, ${ }^{62}$ and the bill was enacted. In light of this legislative history, it is apparent that Congress intended the oil and gas leasing act of 1927 to constitute "recognition" of Indian property interests in reservations established by Executive order; therefore, any subsequent taking of such land or rights therein should be accompanied by compensation. ${ }^{53}$

vation. But let us go a little further into the question than mere legal technicalities and determine our moral obligation to our wards ....

MR. HIASTINGS. Is not the only question involved here whether or not to put an Executive order reservation on the same footing with a treaty reservation?

MR. CA.RTER. Yes, that is the question ....

50. Id. at 4576-78. Compare the remarks of 31r. Sproul the previous year, 67 Cosc. Rec. 11381 (1926) ("The third [type of reservation] was that made by the President without any legal authority ... . It amounts to nothing. It is nothing.").

51. 68 CoNG. REC 4581 (1927); see id. at 4703-04 (extended remarks of Mfr. Mrorrow).

52. See Hearings onr S. 4893 Before the Senate Committee on Indian Affairs, 69th Cong., 2d Sess. (1927) ; 68 Cong. Rec. 2793-95 (1927).

53. It might be argued that the 1927 statute could not vest title in the Indian tribes in the absence of specific words of vesting. Ordinarily, words allegedly creating vested interests are construed against the grantee of public domain, Dubuque \& Pac R.R. v. Litchfield, 64 U.S. (23 How.) 66,88 (1859), but the general rule in Indian law is that tribal rights vest when, under all the circumstances of the case, a congressional intention exists to "recognize" Indian rights of use and occupancy, see Shoshone Tribe of Indians v. United States, 299 U.S. 476, 485 (1937) (treaty language, "set apart for the absolute and undisturbed use and occupation," conveys full fee for compensation purposes); Choste v. Trapp, 244 U.S. 665, 67475 (1912) (statutory grant of privilege of tax-exemption construed to vest a compensable interest if Congress so intended); Worcester v. Georgia, 31 U.S. (6 Pet.) 515, 553 (1832) (Mirshall, C.J.) (treaty reserving lands for "hunting grounds" interpreted to vest title for all purposes). See also Jones v. Mreehan, 175 U.S. $1,1.1$ (1899) (treaty language construed in the "sense in which ... [it] would naturally" be understood by the Indians"). The language of Executive orders is similar to that of treaties. Compare the usual Executive order language-to set aside for "use and occupancy," FEDERAI INDIAN LAw 617-rith treaty language in the Shosione case, sispo"to set apart for the absolute and undisturbed use and occupation." See note 74 infro for other example's of treaty language.

It might further be argued that statutory language relating to mineral proceeds may not be construed to recognize complete Indian title to Executive-order lands. But "there is no particular form for congressional recognition of Indian right of permanent occupancy. It may be established in a variety of ways but there must be the definite intention by congressional action or authority to accord legal rights, not merely permissive occupation." Tee-Hit-Ton Indians v. United States, 348 U.S. 272, 277-78 (1955). (Emphasis added.) Using this rule, the Tee-Hit-Ton Court interpreted its earlier decision, United States v. Alcea Band of Tillamooks, 329 U.S. 40 (1946). There Congress had passed a special jurisdictional statute to hear the claims of the Tillamook Indians for the talking of land reserved by unratified treaties. Neighboring tribes, with ratified treaties, had had their rights protected. Tee-Hit-Ton interpreted Alcea to mean that the congressional in- 
Interpreting the 1927 statute as an act of recognition is consistent with the fact that Congress has not in practice discriminated between the property interests of tribes residing on treaty and Executive-order reservations. ${ }^{\text {o4 }}$ Since 1883, for example, it has given the Indian tribes proceeds from the sale of metallic minerals and timber under statutes applicable to "lands of any Indian reservations." 55 And although the Executive has in the past returned Executive-order reservations to the public domain without compensation," whenever Congress has reduced or revoked an Executive-order reservation, it has compensated the affected tribes in the same manner as it compensated for the taking of treaty lands. ${ }^{57}$ Furthermore, Congress has treated all reservations alike for purposes of annual appropriations, expenditures of the Bureau of

tention in passing the statute had been to "equalize the Tillamooks with the neighboring tribes," and therefore the statute was a congressional direction to pay. 348 U.S. at 284. So, although (1.) the jurisdictional statute was strictly limited to "legal and equitable" claims, and (2) under Tee-Hit-Ton the Tillamooks claim, based as it was on original Indian title, was neither legal nor equitable, the Tillamooks recovered. Thus, under Alcea, as read by Tee-Hit-Ton, statutory language is ignored to give determinative weight to congressional intent.

54. Sioux Tribe of Indians v. United States, 316 U.S. $317,326,328,330-31$ (1942), states that Congress bclieved a difference to exist between treaty and Executive-order reservations, not that Congress acted as if a difference existed. Indeed, the only statutory language indicating congressional belief that Indians did not have vested rights in Executive-order reservations is contained in two statutes stating that "nothing herein contained shall be construed as recognizing title or ownership of said Indians." But these same statutes contain provisions granting the tribes compensation for the takings of Executive-order land. Act of July 1,1892, ch. 140, 27 Stat. 64; Act of Feb. 20, 1893, ch. 147, 27 Stat. 470; see 67 Cong. REc. 10917 (1926) (remarks of Senator Curtis that he Included these compensation provisions in the belief that the Indians held equitable title).

55. 22 Stat. 590 (1883), as amended, 25 U.S.C. $\S 155$ (1958); 25 Stat. 673 (1899), 25 U.S.C. $\S 196$ (1958); 36 Stat. 857 (1910), 25 U.S.C. $\$ 407$ (1958); 41 Stat. 33 (1919), as amended, $\S 399$ (1958). (Emphasis added in all statutes.) An exception is a reservation leasing act, 26 Stat. 795 (1891), 25 U.S.C. $\$ 397$ (1958), interpreted to apply to treaty and statutory reservations, see Uintah Lands, 25 Interior Land Dec. 408, 41112 (1897). This act, however, did not imply that mineral rights in Executive-order reservations could be leased under the general mineral leasing acts for the public domain. McFadden v. Mountain View Min. \& Mill. Co., 97 Fed. 670, 673 (9th Cir. 1899), rev'd on jurisdictional grounds, 180 U.S. 533 (1901) ; Gibson v. Anderson, 131 Fed. 39, 41 (9th Cir. 1904). 43 Stat. 244 (1924), 25 U.S.C. $\$ 398$ (1958), also provided for gas and oil leases only in treaty and statutory reservations, but was specifically extended to Executive-order reservations by the 1927 statute to achieve a uniform treatment of Indian property interests. See 44 Stat. 1347 (1927), 25 U.S.C. \& 398a (1958); notes 42, 49 supra.

56. Sioux Tribe of Indians v. United States, 316 U.S. 317, 330 (1942).

57. See 67 Cong. Rec. 10920-21 (1926) (remarks of Senator La Follette with respect to compensation by acts of Congress for takings of Executive-order lands); 1926 Scualc Hearings II, at 57-58; note 42 supra. Contra, Act of May 29, 1908, ch. 216, § 25, 35 Stat. 457. Compare Act of July 1, 1892, ch. 140, 27 Stat. 62, and Act of Feb. 20, 1893, ch. 147, 27 Stat. 469 (reduction in size of Executive-order reservations), zvith Act of April 23, 1904, ch. 1484, 33 Stat. 254, and Act of March 3, 1905, ch. 1452, 33 Stat. 1016 (reduction in size of treaty reservations). 
Indian Affairs, ${ }^{58}$ permanent capital improvements on reservations, ${ }^{60}$ and termination of federal control over specific tribes. ${ }^{c 0}$

A 1958 statute giving a federal district court jurisdiction over a quiet-title action between two Indian tribes occupying an Executive-order reservation ${ }^{\circ 1}$ might be cited as evidence militating against interpretation of the 1927 oil and gas leasing statute as an act of recognition. For in addition to extending jurisdiction to the Arizona District Court, the 1958 statute declared the disputed lands "to be held in trust" for the litigant tribes. "2 If the oil and gas leasing statute of 1927 constituted an act of recognition vesting property interests in tribes on all Executive-order reservations then in existence, that part of the 1958 jurisdictional statute declaring the lands of a particular Executive-order reservation to be held in trust for resident tribes would be supererogatory. Arguably, therefore, the 1958 Congress did not believe that Indian tribes had vested property interests in Executive-order reservations and a fortiori did not interpret the oil and gas leasing statute of 1927 as an act of recognition. The federal district court given jurisdiction so implied when it observed in dictum that

an unconfirmed executive order creating an Indian reservation conveys no right of use or occupancy ... beyond the pleasure of Congress or the President. ... [A]s long as the lands in question had status only as executive order lands, the parties to this suit could have no interest therein amenable to judicial determination. ${ }^{63}$

But, passing a possible distinction between "title" for purposes of amenability to judicial process and "title" for purposes of compensability upon a govern-

58. E.g., Act of June 30, 1919, ch. 4, 41. Stat. 3 (1919) (typical appropriations act; provisions relate to need not character of title, except for special treaty obligations); see 1927 Honse Hearings 90; $i d$. at 103 (remarks of Commissioner Burke: "We have always conisistently taken the position that the Indians have the same rights in executive order Indian lands as treaty lands."); cf. 34 Ors. ATr'Y GEN. 171, 181 (1924) ("The important matter here, however, is that neither the courts nor Congress have made any distinctions as to the character or extent of the Indian rights, as between executive order reservations and reservations established by treaty or Act of Congress.").

59. See, e.g., 64 Stat. 44 (1950), as amended, 25 U.S.C. $\$ \$ 631-40$ (1958), appropriating $\$ 88$ million for capital improvements for the Navajo and Hopi Tribes although the Hopi reservation was held by Executive order only. See Healing v. Jones, 174 F. Supp. 211,215 (D. Ariz. 1959)).

60. See, e.g., 68 Stat. 718 (1954), as amended, 25 U.S.C. $\$ \$ 564-564 \mathrm{w}$ (1958). These statutes define tribal property as that property which "belongs to the tribe." See 6S Stat. 718 (1954), 25 U.S.C. $\$ 564$ (a) (1958). The definition is based upon a report of the Bureau of Indian Affairs stating that Executive-order reservations are held in trust for the tribe by the Government. See H.R. REP. No. 2503, 82d Cong., 2d Sess. 1-7, 23-25, 60-67 (1953).

61. Act of July 22, 1958, No. 85-547, 72 Stat. 403 .

62. See Healing v. Jones, 174 F. Supp. 211, 216 (D. Ariz. 1959) ("Here Congress undertook by the enactment of the Act of July 22, 1958, to convey to certain Indians equitable interests in the lands theretofore described in the executive order .... [Therefore], from the date of that enactment, the ... [Indian tribes] had vested equitable interest therein capable of judicial recognition ...."); 104 CoNG. REC 13066 (1958).

63. 174 F. Supp. at 216. 
mental taking, neither that court, nor any other, has considered the effect of the 1927 statute. And no evidence exists that the 1958 Congress adverted to the existence, let alone the title implications, of the 1927 act. ${ }^{04}$ The 1958 jurisdictional statute was summarily considered and passed by Congress to allow judicial settlement of an old and recurrent dispute between Indian tribes. ${ }^{65}$ Since no claim against the United States was involved, the Indian Claims Commission Act was inapplicable, and a special jurisdictional statute was thought necessary to provide the tribes with access to the courts. ${ }^{00}$ The provision vesting rights in the litigant tribes was probably included by the Indian lawyers who drafted the statute ${ }^{67}$ to prevent the district court from declining jurisdiction on the grounds that the interests it was asked to adjudicate were subject to extinguishment by fiat. Nevertheless, a committee report reasonably indicates a congressional belief that Indian property interests were not vested and an intent to convert "present interests" in the particular reservation into title. $^{68}$ Even so, if the 1927 Congress recognized tribal property rights in Executive-order reservations, such a belief would be irrelevant; rights of use and occupancy had already been transmuted into compensable interests, and the 1958 : Congress was bound by its predecessor.

Tribal property interests in Executive-order reservations in Alaska are affected by factors not relevant to comparable interests in the rest of the United States. Although Indians in other states had been settled on reservations by 1919, most Alaskan natives then and now reside on land they claim by immemorial possession. ${ }^{69}$ In 1936 , to protect them from an influx of white settlers and to ensure continuance of their occupancy rights, Congress delegated authority to the Secretary of the Interior to designate reservations in Alaska. ${ }^{70}$ Pursuant to this statute, the Secretary has designated six reservations covering $1,540,600$ acres of land..$^{71}$ No court has decided whether tribes on these reservations have compensable interests. In Hynes v. Grimes Pack-

64. See H.R. Rep. No. 1942, 85th Cong., 2d Sess. (1958); 104 CoNG. Rec. 13066, 13196 (1958).

65. H.R. ReP. No. 1942, supra note 64; 104 CoNG. Rec. 13196 (1958).

66. See H.R. Rep. No. 1942, supra note 64 .

67. Ibid.

68. Ibid.

69. See 8 Ala. L. Rev. 170, 174 (1955).

70. 49 Stat. 1250 (1936), 48 U.S.C. $\S 358$ a (1958). For the purposes of the 1936 statute, see H.R. REp. No. 2244, 74th Cong., 2d Sess. (1936); S. REp. No. 1748, 74th Cong., 2d Sess. (1936). The 1936 statute made the Wheeler-Howard Act, 48 Stat. 984 (1934), 25 U.S.C. $\$ \$ 461-79$ (1958), applicable to Alaska. The Wheeler-Howard Act suspended the Indian General Allotment Act, 24 Stat. 388 (1887), as amended, 25 U.S.C. $\S 331$ (1958), and provided for the incorporation of Indian tribes, see 48 Stat. 984 (1934), 25 U.S.C. \& 461 (1958). The reservations were necessary to give jurisdictional boundaries to the incorporated tribe. H.R. REP. No. 2244, 74th Cong., 2d Sess. 4 (1936).

71. S. REP. No. 1366, 80th Cong., 2d Sess. 6 (1948) ; see H.R. REP. No. 2503, 82d Cong., 2d Sess. 1386-99 (1952) (all reservations marked "DP" were designated pursuant to the 1936 statute). 
ing $\mathrm{Co.}_{.}{ }^{72}$ however, Mr. Justice Reed noted in dictum that while the statute was a valid delegation of authority to the Secretary of Interior to withdraw public domain, it was not, in the absence of specific words of vesting, a delegation of congressional authority to create compensable property rights.

But committee reports on the 1936 act state that the statute was intended to fulfill a promise in the Act of May 17, 1884, that Congress will provide a means by which Indians "may acquire title" to the lands they use and occupy. ${ }^{73}$ In addition, courts have uniformly held that no specific words of vesting are necessary to create vested equitable interests in reservations created by statute or treaty using words similar to or identical with the language of the 1936 statute. ${ }^{74}$ Mr. Justice Reed distinguished these congressional enactments on the ground that they dealt with specific claims and individual tribes while the 1936 delegation to the Secretary of the Interior affected the entire public domain in Alaska. General delegations of authority, however, have characterized all Indian legislation since 1934. ${ }^{75}$ And the Secretary's authority under the statute is carefully restricted to those lands previously reserved for Indian use and occupancy or "actually occupied" by Indian tribes. ${ }^{\text {i0 }}$ Moreover, the suggestion that designation of reservations does not vest property rights

72. 337 U.S. 86 (1949). The Packing Company sued the regional director of the Fish and Wildlife Service, to enjoin enforcement of a regulation promulgated under authority of the Alaska Fisheries Act (White Act), 43 Stat. 464 (1924), 48 U.S.C. $\$ \S 221-28$, 23234 (1958), which regulated fishing rights off the cosst of Alaska. Id. at 88-89, 100. The regulation protected fishing rights of the Karluk Indians in coastal waters within a reservation created under authority of the 1936 statute, 49 Stat. 1250 (1936), 48 U.S.C. \$358a (1958). Id. at 89. Mrr. Justice Reed upheld the validity of the reservation but denied the validity of the regulation on the ground that it violated a clause in the White Act providing all parties with equal access to coastal waters for fishing purposes. Id. at 123, 127.

73. H.R. Rep. No. 2244, 74th Cong., 2d Sess. 3 (1936) ; S. REP. No. 1748, 74th Cong., 2 d Sess. 2 (1936).

74. Compare 49 Stat. 1250 (1936), 48 U.S.C. $\$ 35 \&$ (1958) ("designate as an Indian reservation"), with Treaty With the Wea Tribe of Indians, Oct. 2, 1818, 7 Stat. 186 ("to be holden by the said tribe as Indian reservations are usually held"); Act of May 28,1937 , ch. 283, 50 Stat. 241 ("extended to include"), and Treaty With the Ifemomonee Tribe of Indians, Oct. 18, 1848, 9 Stat. 952 ("to be held as Indians' lands are held"). The courts have uniformly interpreted such vague words as giving to the Indian tribes a vested property interest. See, e.g., United States v. Klamath \& Iloadoc Tribes of Indians, 304 U.S. 119, 123 (1938) (treaty language: "held and regarded as an Indian reservation"). See also Worcester v. Georgia, 31 U.S. (6 Pet.) 515, 553 (1832) (Mlarshall, C.J.) ("hunting grounds").

75. See Wheeler-Howard Act, 48 Stat. 987 (1934), 25 U.S.C. $\$ 476$ (1958) (gencral delegation of authority to the Secretary of Interior to incorporate tribes under constitutions of their own choice); Indian Claims Commission Act, $\$ 2,60$ Stat. 1050 (1946), 25 U.S.C. \& 70a (1958) (general delegation of authority to the Indian Claims Commission to hear all claims accruing prior to Aug. 13, 1946); 28 U.S.C. \$ 1505 (1958) (general delegation of authority to the Court of Claims to hear all claims accruing aiter Aug. 13, 1946) ; 18 U.S.C. \& 1162 (1958) (general delegation of civil and criminal jurisdiction to the states).

76. 49 Stat. 1250 (1936), 48 U.S.C. § 358a (1958); see United States v. Libby, McNeil \& Libby, 107 F. Supp. 697, 700 (D. Alaska 1952). 
in affected tribes renders much of the 1936 statute nugatory. Since, under the right of conquest theory, the Executive may protect the Alaskan natives' unextinguished aboriginal right of use and occupancy against all but the sovereign, ${ }^{77}$ designation of a reservation would not change tribal rights and would render the statutory provision for tribal ratification of designated reservations a sham. ${ }^{78}$ Legislative intent as expressed in the committee reports on the 1936 statute, the general congressional policy, evidenced by the legislative history of the 1927 statute, that tribes shall have compensable property interests in all reservations regardless of origin, and the emasculating effect on the 1936 statute of a contrary construction, suggest the conclusion that Congress intended by delegating to the Secretary the authority to "designate reservations" to create in him the power to vest equitable title in Alaskan tribes.

The 1936 statute and the oil and gas leasing act of 1927 create compensable tribal property interests in Executive-order reservations in Alaska and the other states respectively. This interpretation assures uniform treatment of Indian property rights in treaty, statutory, and Executive-order reservations, infuses meaning into the 1946 extension of jurisdiction to the Court of Claims for Indian claims arising under "Executive Orders of the President," and, in combination with such extension of jurisdiction, affords a meaningful and needed protection for an important source of Indian property interests.

77. E.g., United States v. Berrigan, 2 Alaska 442 (1905).

78. See 49 Stat. 1250 (1936), 48 U.S.C. $\S 358$ a (1958). Determination of the extent of aboriginal rights of use and occupancy is difficult, see, e.g., Tlingit \& Haida Indians v. United States, $177 \mathrm{~F}$. Supp. 452 (Ct. Cl. 1959), and negotiations culminating in tribal ratification are a practical means of settling these Indian land claims. 